\title{
Desenvolvimentismo e política econômica: um cotejo entre Vargas e Perón
}

\author{
Pedro Cezar Dutra Fonseca * \\ Andrés Ferrari Haines **
}

\begin{abstract}
Resumo
O artigo compara a política econômica de duas experiências desenvolvimentistas na América Latina: o primeiro período governamental de Vargas (Brasil, 1930-1945) e Perón (Argentina, 1946-1955). Embora aceite a semelhança entre ambas, comumente mais enfatizada pela literatura, procura mostrar certas diferenças entre elas em matéria de natureza econômica. Defende que, enquanto Vargas centravase em medidas para mudar a estrutura econômica do país, com ênfase à industrialização, Perón deu maior prioridade à redistribuição de renda do que a mudanças no modelo econômico, o qual já vinha sendo implementado na Argentina antes de seu governo.
\end{abstract}

Palavras-chave: América Latina; Vargas, 1882-1954; Perón, 1895-1974; Populismo.

\begin{abstract}
Developmentalism and economic policy: a comparison between Vargas and Perón

This paper compares economic policy characteristics of two developmentalist experiences in Latin America: the first Vargas administration (Brazil, 1930-1945) and the Perón administration (Argentina, 1946-1955). Although certain similarities exist between them (which are usually stressed in the literature), this article seeks to reveal some differences that are economic in nature. While Vargas focused on measures that would change the country's economic structure and with an emphasis on industrialization, Perón prioritized income distribution more than any changes to the economic model that had been implemented before his administration took office.
\end{abstract}

Keywords: Latin America; Vargas, 1882-1954; Perón, 1895-1974; Populism.

JEL N16, N26, P52.

\section{Introdução}

Usualmente, os governos de Vargas (1930-45 e 1951-54) no Brasil e de Perón (1946-55) na Argentina são considerados como exemplos típicos do populismo latino-americano do século XX. As análises tendem a convergir que ambos encabeçaram governos intervencionistas, de cunho mais ou menos nacionalista, os quais procuraram estabelecer a mediação entre diferentes segmentos e classes em um momento crucial da história de seus países, qual seja, da transição entre um

\footnotetext{
* Professor Titular do Departamento de Ciências Econômicas da Universidade Federal do Rio Grande do Sul (UFRGS) / Pesquisador do CNPq, Porto Alegre, RS, Brasil. E-mail: pedro.fonseca@ufrgs.br. Agradecemos a colaboração dos bolsistas de Iniciação Científica/CNPq André Augustin e Leonardo Staevie Ayres.

** Professor do Núcleo de Estudos Internacionais da Universidade Federal do Rio de Janeiro (UFRJ), Rio de Janeiro, RJ, Brasil. E-mail: afhaines@hotmail.com.
} 
modelo econômico agrário-exportador para outro, centrado no desenvolvimento industrial por meio da substituição de importações. As análises político-sociológicas frisam a semelhança entre eles por se tratarem de líderes carismáticos, capazes de estabelecer uma liderança personalista sobre as classes trabalhadoras urbanas emergentes e, assim, expressarem suas reivindicações, atender parte delas e ao mesmo tempo controlá-las e administrá-las. Cardoso e Faletto (1977, p. 103) muito bem essa abordagem facilmente associada ao Brasil e à Argentina nos períodos governamentais, ao vincular o fenômeno do populismo à transição entre uma sociedade tradicional/agrária a outra, urbano/industrial, como:

o elo através do qual se vinculam as massas urbanas mobilizadas pela industrialização - ou expulsas do setor agrário como conseqüência de suas transformações ou de sua deterioração - ao novo esquema de poder; e converter-se-á na política de massas, que tratará de impulsionar a manutenção de um esquema de participação política relativamente limitado e baseado em uma débil estrutura sindical que não afetou as massas rurais nem o conjunto do setor popular urbano (Cardoso; Faletto, 1977, p. 103).

A dupla face de Vargas e de Perón - apelo às "massas" emergentes e autoritarismo, respaldado nos sindicatos, mas com controle sobre suas lideranças - é a tônica da análise de diversos autores. Weffort (1977, p. 51) lembra que o populismo "foi um modo determinado e concreto de manipulação das classes populares, mas foi também um modo de expressão de suas insatisfações". Essa "dubiedade" reforça-se ao analisarem-se os discursos de Vargas e Perón, pois ambos por reiteradas vezes procuraram firmar sua imagem como políticos com certa equidistância dos extremos, críticos tanto do capitalismo liberal como do comunismo. No contexto da Guerra Fria, após 1946, não raramente ambos se manifestaram como críticos ao alinhamento automático tanto aos Estados Unidos como à URSS. Tal postura de "independência" e busca de um modelo econômico e político próprio, mesmo que retórica, se em algumas conjunturas logrou ampliar suas bases de sustentação e de convencimento, em outras implicou dificuldades de governabilidade. Skidmore (1969, p. 94-5) assim sintetiza: "É temido, naturalmente, pela direita, devido ao transtorno que poderia trazer ao status quo. Desdenhado pela esquerda marxista disciplinada, pela sua irresponsabilidade e 'mistificação' das massas (...)".

Este artigo tem por objeto a comparação entre Vargas e Perón com ênfase em temas de natureza econômica e sua principal fonte de pesquisa são os discursos (pronunciamentos oficiais, entrevistas, relatórios) do primeiro período presidencial de Vargas (1930-1945) e de Perón (1946-1955), associados a medidas de política econômica adotadas por seus governos. Não se pretende arrolar, com exaustão, as políticas econômicas executadas com o propósito de analisá-las individualmente, mas focar o tratamento de ambos a alguns dos principais temas controversos da conjuntura em que governaram, como a polaridade entre agricultura e indústria e 
distribuição de renda versus crescimento econômico, os quais, por sua relevância no debate da época, permitem que se detecte com mais precisão semelhanças e diferenças, podendo-se traçar um paralelo entre ambos. Para tanto, o recurso metodológico de recorrer aos discursos deve-se à possibilidade de os mesmos auxiliarem sobremaneira a detectar intenções e projetos, ainda que por vezes não consigam, quando de sua execução, êxito no alcance dos objetivos planejados, ou talvez nem cheguem a materializar-se como medidas efetivas de política econômica. Assim, sem ignorar as contribuições anteriormente mencionadas que ressaltam as semelhanças e os padrões repetitivos entre um e outro governo, trabalhar-se-á com a hipótese segundo a qual ambos também apresentam diferenças significativas, as quais não podem ser ignoradas. Muitas vezes, são subestimadas ou obscurecidas nos rótulos mais generalizantes de "populistas", "autoritários", "personalistas", "intervencionistas" dentre outros adjetivos. Tem-se como corolário de trazer à tona tais diferenças ajudará na compreensão do significado histórico tanto do peronismo como do varguismo. Assume-se, para tanto, o pressuposto metodológico de que ambos constituem respostas próprias a demandas e problemas de seus países, pelo que a proximidade temporal e traços comuns não podem apagar as diferenças, com o risco de se simplificar e generalizar fenômenos complexos.

As seções 1 e 2, a seguir, abordam, respectivamente, os governos de Vargas e Perón. Nelas, procura detectar-se qual a prioridade de cada um no que tange ao rumo da economia de seus países, mormente sobre como a industrialização - tema central nos debates da época - era vista por ambos e como se inseria nos projetos governamentais. No caso de Vargas, enfoca seu primeiro período governamental porque se indaga se tanto ele como Perón representaram nova postura com relação a seus antecessores principalmente quanto aos temas antes mencionados. Saber se era propósito central de ambos redirecionar a economia de seus países em favor de um projeto de industrialização como alternativa ao modelo econômico fortemente assentado na exportação de produtos primários, vigente tanto na Argentina como no Brasil, desde meados do século XIX até as primeiras décadas do século XX. Em outras palavras, pretende-se responder à questão se havia ou não um projeto consciente de industrialização em cada um dos governos e se as propostas de política econômica possuíam centralidade no mesmo. Adianta-se, desde já, que se pretende trabalhar com a hipótese de que há uma diferença muito grande entre os dois governantes nesse aspecto, pois a resposta à questão é positiva para o caso de Vargas e negativa para o governo Perón. Pretende-se demonstrar, em adição, a segunda hipótese que é um corolário da primeira, segundo a qual Vargas deixa explícito seu projeto de romper com o modelo agroexportador e propor a industrialização como alternativa, ao passo que Perón não prioriza conjunto similar de mudanças na esfera produtiva, mas principalmente na distribuição. A última seção, à guisa de conclusão, retomará a comparação entre ambos. 


\section{Vargas e a industrialização como superação ao modelo agraexportador}

A defesa da industrialização do Brasil por parte de Vargas antecede sua ascensão à presidência do país em 1930. Desde suas primeiras manifestações em que há registro, ainda da época de estudante, nota-se a defesa da necessidade da diversificação econômica do país como forma de resguardá-lo das crises e fortalecê-lo economicamente. Essa posição vinha ao encontro dos ideais positivistas do governo do Rio Grande do Sul, com quem Vargas identificava-se e em cujo partido, o Partido Republicano Rio-Grandense (PRR), iniciou sua carreira política. A diversificação, no caso, era entendida na maior parte das vezes como dentro do setor primário, com a defesa da policultura e da produção para o mercado interno. Não se criticava em si a agroexportação, mas o fato de a mesma concentrar-se em um ou dois produtos, em um período em que o café perfazia mais de dois terços do valor exportado pelo Brasil. Como exemplo, pode citar-se o discurso em homenagem a Afonso Pena, ao visitar o Rio Grande do Sul em 15 de agosto de 1906, quando Vargas o saudou em nome dos estudantes: "Amarga resultante para quem se vê coato a comprar, manufaturados do estrangeiro, os gêneros da própria matéria-prima que exporta" (Fonseca, 1989, p. 35).

Nota-se, no contexto, uma postura de Vargas já mais arrojada, pois se manifestava adepto de uma proposta de diversificação que se estendia ao beneficiamento das matérias-primas locais, as então denominadas "indústrias naturais". Essa expressão acenava para a complementaridade entre interesses agrários e industriais, pois se tratava fundamentalmente da agroindústria, responsável, de um lado, por gerar demanda para a produção primária e, de outro, por prescindir de protecionismo para garantir seu próprio mercado favorecido. Dentre outros motivos, pela barreira representada pelo custo dos transportes e a própria taxa cambial desvalorizada, em várias conjunturas, no caso do similar importado. A concepção, assim, incluía a defesa das atividades industriais, mas, a rigor, não chegava a contrariar a tese largamente aceita, segundo a qual o Brasil era um país de "vocação agrária”.

Com a assunção à Presidência, a opção de Vargas pela industrialização foi gradualmente se tornando mais explícita e frequente até atingir, em meados da década de 1930, a centralidade de seus discursos com temática econômica. A interpretação segundo a qual 1930 representou um ponto de ruptura de um modelo centrado na agroexportação em prol de outro, com epicentro na indústria - o modelo de substituição de importações - é clássica na literatura sobre economia brasileira desde Furtado ([1959] 1977) e Tavares (1972). Não cabe aqui repisar toda a argumentação de ambos. Ela pode ser sintetizada como resultado do estrangulamento externo agudo, decorrente da crise internacional, associado à opção do governo por manter o nível de renda da economia cafeeira por meio de desvalorização cambial e 
financiamento, com o crédito ancorado em emissão monetária (ou mesmo impostos, como mostrariam trabalhos posteriores). $\mathrm{O}$ efeito multiplicador de tal intervenção sobre a demanda agregada doméstica contribuiu para o deslocamento do "centro dinâmico" da economia, com a indústria crescendo a taxas sem precedentes: $11,2 \%$ anuais entre 1933-39, enquanto o crescimento da agricultura alcançava pouco mais de $2 \%$ entre 1934-37, para uma taxa média da economia de 6,5\% ao ano (Furtado, 1977, p. 195; Villela; Suzigan, 1973, p. 211-212).

Salienta-se, ainda, que o crescimento industrial não se restringiu aos bens de consumo não duráveis - os maiores responsáveis porcentualmente pelo valor agregado da indústria como alimentos, têxteis e bebidas. Os segmentos industriais que mais cresceram entre 1933-39 (conquanto muitas vezes partissem de uma base pequena, o que colabora para majorar a magnitude do crescimento porcentual) foram os de papel e papelão, metalúrgica e minerais não metálicos, enquanto, entre 193237 , a produção física de ferro gusa aumentou $240 \%$, a de aço em lingotes $123 \%$ e a de laminados $142 \%$. No mesmo período, o consumo aparente de cimento cresceu $110 \%$ e o de cimento nacional 282\% (Villela; Suzigan, 1973, p. 216; Aureliano, 1981, p.123, 132; Baer, 1969, p.80-81).

Embora o crescimento industrial fosse expressivo, do ponto de vista metodológico, não basta o registro das referidas taxas para que se corrobore a hipótese de ter havido um projeto governamental voltado à industrialização. Elas podem ajudar como uma primeira aproximação (ou pelo menos para rejeitar a hipótese alternativa, que a indústria não crescera ou não houve a "mudança de modelo"), posto que o crescimento industrial, em tese, poderia resultar de medidas não necessariamente intencionais do governo. O próprio Furtado (1977, p. 193) assim entende, ao afirmar que "a recuperação da economia brasileira, que se manifesta a partir de 1933, não se deve a nenhum fator externo e sim à política de fomento seguida inconscientemente no país e que era subproduto da defesa dos interesses cafeeiros". Há de se considerar, todavia, que a interpretação de Furtado decorre em boa medida do instrumental utilizado: ao centrar sua análise nas políticas monetária, fiscal e cambial, pôde de forma pioneira mostrar o governo brasileiro lançando mão de uma política anticíclica que, ao garantir o nível de renda da economia cafeeira, logrou obter um impacto maior que o almejado em todo o conjunto da economia. Pode-se asseverar que o estudo das citadas políticas econômicas instrumentais nem sempre permite detectarem-se as intenções dos policymakers, posto que a implementação das mesmas prende-se, na maior parte das vezes, a razões inerentes às políticas de estabilização, de busca do equilíbrio macroeconômico ou das contas públicas (ou a uma lógica mais instrumental que propriamente "finalística") como do nível geral de preços, orçamento público ou balanço de pagamentos (Fonseca, 2003, p. 134). 
Esses objetivos, em tese, podem ser encampados por diferentes governos, por opção ou necessidade, independentemente da existência de um projeto econômico-político de maior envergadura. Detectar, todavia, um projeto de longo prazo (o qual, ao contrário de um "plano de governo", nunca é evidente por si mesmo) é sempre um desafio a economistas e demais cientistas sociais. Para ser desnudado, faz-se necessário recorrer a uma metodologia que vá além dos dados ex-post das variáveis conjunturais. Devem incluir-se, no entanto, na reconstituição histórica, não só outros elementos, como considerar as medidas adotadas, dentre elas, as mudanças na legislação econômica e a criação de instituições e órgãos no aparelho estatal, mas também buscá-los como material empírico ao discurso e demais pronunciamentos das autoridades, capazes de ajudar a desvendar as razões de suas opções. Tal procedimento torna-se necessário ante a hipótese inicial sobre a centralidade do desenvolvimento econômico no projeto de Vargas, este entendido como industrialização por meio da substituição de importações.

A análise do discurso de Vargas durante os quinze anos que compreendem seu primeiro governo não deixam dúvida sobre a intencionalidade da industrialização, a qual gradualmente se tornou o epicentro de um projeto, em geral, denominado, com certa licenciosidade, de "nacional-desenvolvimentista". Já, em 1931, cita Vargas (1938, v.1, v.1, p.163; grifos nossos) o protecionismo alfandegário aos produtos industriais passava a ser entendido como "fator decisivo, sem dúvida, ao nosso progresso econômico. (...) As tabelas das alfândegas devem refletir estes critérios". Época em que ainda se fazia uso do termo progresso, de matiz positivista. Gradualmente, passou a ser substituído por desenvolvimento econômico como no discurso pronunciado em 7 de setembro de 1936: "Atingimos elevado estágio de desenvolvimento cultural, institucional e econômico. (...) Já não somos um país exclusivamente agrário, jungido à luta pelos mercados consumidores de matériasprimas e esmagado pelo peso das aquisições de produtos industriais". Fica clara a referência negativa explícita na expressão “exclusivamente agrário". Esta denota que

(1) A análise aqui se centra no primeiro governo de Vargas porque, além do motivo já mencionado de se pretender mostrar a mudança de modelo com relação ao governo anterior, ao fato de que, com respeito ao segundo período, de 1951 a 1954, há relativo consenso na literatura sobre sua opção industrializante. A defesa desta tese respalda-se não só no nacionalismo e no clima de radicalização política que desaguou no suicídio de Vargas, como em fatos como a criação da Petrobrás e a Instrução 70 da Superintendência da Moeda e do Crédito (Sumoc), responsável pela formulação da política monetária a qual, diante da crise cambial, introduziu o regime de leilões de câmbio com base em cinco categorias para importação tendo como critério a "essencialidade" dos bens. Definiase claramente segundo os interesses da produção industrial: os insumos e bens de capital integravam as primeiras faixas, enquanto nas últimas categorias arrolavam-se aqueles tidos como supérfluos, assim, englobando os bens de consumo que possuíam similar nacional. Protegia-se, portanto, duplamente a indústria nacional: nos custos, com o câmbio baixo em suas importações e na demanda, com barreira cambial com relação aos concorrentes estrangeiros. Já, as atividades exportadoras passaram a perceber um bônus de Cr\$ 5,00 por dólar (café) e de Cr\$10,00 (demais itens), acima da taxa oficial. As análises convergem quanto à resultante de proporcionar uma transferência de renda do setor exportador para as atividades industriais e voltadas ao mercado doméstico, pois aumentava sua lucratividade em termos relativos. 
não se trata a limine de negar a importância das atividades agrárias ou exportadoras, mas de rejeitar tais atividades como sendo a principal variável responsável pela determinação da demanda agregada, posto que deveriam ceder espaço às atividades manufatureiras voltadas ao mercado doméstico. Em outro pronunciamento, ao final de 1936, registra-se a explicitação da tese de que o desenvolvimento era a tarefa principal do poder público, o qual possuía etapas a serem vencidas e o novo relacionamento entre Estado e iniciativa privada não deveria ocorrer em prejuízo desta última, "antes, amparando-a e favorecendo o surto de novas culturas e indústrias" (Vargas, 1938, v. 4, p. 182, 209).

O desenvolvimento econômico paulatinamente foi transformando-se não apenas em um ponto de uma retórica enaltecedora da ampliação da agenda do estado, mas tornando-se a própria razão de ser da política econômica e ação estatal nas mais diversas áreas. A marca do discurso de Vargas ao longo desse período é reiterar a responsabilidade do governo como agente transformador. Sua tarefa maior era desenvolver o país, sendo necessário superar o atraso o qual passa a ser associado a um passado de marasmo rural, agrário, "oligárquico", que deveria dar espaço a um Brasil industrial bem pujante econômica e socialmente mais equilibrado. Com clareza, a melhoria das condições sociais viria como decorrência do desenvolvimento econômico. A tarefa do governo era, sobretudo, com o desenvolvimento, ou seja, com a industrialização (sem deixar de mencionar a modernização agrícola que supõe, por sua vez, maior interação entre a produção industrial de insumos e bens de capital com o setor primário).

Não resta dúvida de que os discursos de Vargas já na da década de 1930 evidenciam uma postura deliberada em prol de um projeto de industrialização ou, então, como explicar essa afirmação sua em 7 de setembro de 1936, simbolicamente ao saudar a data da independência: "Já não somos um país exclusivamente agrário, jungido à luta pelos mercados consumidores de matérias-primas e esmagado pelo peso das aquisições de produtos industriais"? (Vargas, 1938, v. 4, p. 182).

No ano seguinte, com a instauração da ditadura do Estado Novo, tal visão torna-se doutrina oficial e frases semelhantes serão repetidas inúmeras vezes: a industrialização passa a ser associada à autonomia nacional, principalmente, pelo contexto da guerra que se aproxima, por exemplo:

Não será exagero atribuir, historicamente, a nossa conduta de incompreensão e passividade ao provincialismo que a Constituição de 1891 estabeleceu e ao reclamo dos países industriais interessados em manter-nos na situação de simples fornecedores de matérias-primas e consumidores de produtos manufaturados. Aquela expressão - 'país essencialmente agrícola' - de uso corrente para caracterizar a economia brasileira mostra, em boa parte, a responsabilidade do nosso atraso (Vargas, 1944, v. 10, p. 53-54). 
Destarte, o discurso de Vargas já nessa época adianta pontos que serão mais tarde consagrados pelo pensamento cepalino, como uma divisão internacional do trabalho perversa aos "países periféricos", a qual explicaria as razões do "atraso" (mais tarde, para Prebisch e Furtado, "subdesenvolvimento") do país. Ademais, por pressões militares, em contexto de véspera de guerra, o avanço da industrialização na direção de ramos mais pesados, como a siderurgia - essencial para a produção de armamentos -, era cada vez maior. A diferenciação entre indústrias "naturais" e "artificiais" - diferenciação que procurava compatibilizar a defesa da agroindústria com a ideologia até então dominante da "vocação agrária" do país - foi sendo superada com a consciência de que era preciso ir além dos ramos tradicionais, como têxtil e alimentos e o estado ingressou na produção siderúrgica com a criação da Companhia Siderúrgica Nacional, em 1941. Era a primeira vez que uma empresa estatal entrava diretamente na produção, sob a justificativa de que a "exploração das riquezas do subsolo e o tratamento industrial dos produtos minerais básicos - carvão, ferro e petróleo - e a criação da metalurgia adiantada são etapas indispensáveis a nossa independência econômica" (Vargas, 1940, v. 7, p. 331-335).

A defesa da industrialização como projeto é cristalina, assim como a associação colonial/agrário/exportador, por um lado, e autonomia nacional indústria/ mercado interno, por outro lado: "O país semicolonial, agrário, importador de manufaturas e exportador de matérias-primas poderá arcar com as responsabilidades de uma vida industrial autônoma, prevendo as mais urgentes necessidades de defesa e aparelhamento. Já não é mais adiável a solução" (Vargas, 1944, v. 10, p. 59).

À luz desses pronunciamentos, pode-se afirmar, com toda a precaução metodológica exigida, a existência de ideologia desenvolvimentista já no primeiro governo de Vargas, pois, com o farto material empírico pesquisado, permite que se detecte claramente a percepção governamental, explícita, voltada à implementação de um projeto em que o desenvolvimento tornava-se a própria razão de ser da ação governamental e que este tinha como ponto pétreo a industrialização do país e a superação de seu passado agroexportador - consciência exaustivamente repetida. Na tipologia weberiana, trata-se de bom exemplo empírico de ação social racional, posto que se orienta por expectativas sobre o comportamento de outrem, com objetivos e valores claramente formulados e consistentes, "utilizando essas expectativas como 'condições' ou 'meios' para alcançar fins próprios, ponderados e perseguidos racionalmente, com sucesso" (Weber, 1992, p. 15).

Os fundamentos empíricos da referida hipótese tornam-se mais sólidos quando se acrescem à análise dos discursos as instituições criadas no período. Se nem sempre é possível depreender com clareza a consciência de um projeto por meio do estudo das políticas instrumentais antes mencionadas, o mesmo não ocorre quando se incorporam à análise as instituições, pois estas geralmente são criadas 
por uma ação deliberada. As instituições não aparecem ao acaso, posto que resultam de um ato intencional: uma lei, por exemplo, depende de um ato volitivo, de uma proposta e uma aprovação, assim como ministérios, órgãos, institutos, conselhos e empresas estatais só podem ser criados por ação deliberada. Sem entrar no debate sobre o que significa instituição, pode-se ter presente que tanto em uma definição mais ampla, à semelhança do institucionalismo clássico, até em uma concepção mais próxima da Nova Economia Institucional, como "regras do jogo", são marcantes as mudanças institucionais induzidas pelo governo a partir da década de 1930, as quais apontam fortemente para evidenciar a existência de um projeto cujo epicentro é a industrialização do Brasil2 .

A própria análise do discurso mostra que, ao longo da década de 1930, emergiram e difundiram-se novas crenças, valores, símbolos e padrões de comportamento. A linguagem oficial atesta-o por meio de termos e expressões já mencionados como "autonomia nacional", "desenvolvimento", "nação", "atraso", "país semicolonial", "aparelhamento", "etapas a vencer" entre outros. Também apareceram leis como o Código de Minas e o Código de Águas, com a regulamentação do subsolo, fundamental na definição do direito de propriedade. As duas constituições, de 1934 e 1937, ampliaram a esfera do Poder Executivo no que tange à formulação das políticas monetária, tributária e cambial, diminuindo o poder dos estados e aumentando as prerrogativas da União. Essa última carta praticamente extingue o federalismo em matéria de natureza econômica, em consonância com a tendência da política.

Dentre tais mudanças institucionais, podem-se ainda citar, por sua importância, a mudança tarifária de caráter protecionista, adotada em 1934, e a criação da Carteira de Crédito Agrícola e Industrial do Banco do Brasil (CCAI) em 1937. A primeira representou aumento da tarifa específica agregada em torno de $15 \%$ e foi resultado de negociação política do governo com líderes industriais então representativos e tidos como "nacionalistas" como Roberto Simonsen e Euvaldo Lodi (Abreu, 1989, p. 86).

(2) A própria definição do que seja instituição é objeto de debate entre as várias correntes abarcadas pelo institucionalismo moderno e a controvérsia extravasa a proposta deste artigo. Assim, a antiga tradição entende por instituição algo semelhante à cultura, envolvendo crenças, valores, símbolos e padrões de comportamento. Chama-se atenção para a complexidade envolvida nas instituições, com cunho fortemente sociológico, acentuando a importância da interdisciplinaridade. Já, para um segundo grupo que compreende a Nova Economia Institucional, instituição tem um sentido mais restrito, lembrando "regras do jogo", em uma concepção mais próxima à teoria dos jogos. Há ainda uma terceira visão, assentada em uma definição de natureza mais histórica, a qual associa instituição a estruturas, organizações ou conjunto de leis, abarcando, portanto, por exemplo, a moeda, o sistema jurídico, as corporações, o sistema financeiro e os organismos econômicos internacionais (para uma discussão mais aprofundada entre as várias correntes do institucionalismo, veja Nelson (1995, p. 80-82); Zysman (1994, v. 3, n. 1, p. 243-283); Conceição (2000, cap. 2). 
Embora se possa discutir a magnitude de seu impacto a curto prazo, pois uma desvalorização cambial em 1935 representou, na prática, maior proteção à produção doméstica ao elevar os preços dos importados, deve-se ter presente que, seja por um instrumento ou outro, evidencia-se a postura do governo de proteção à indústria nacional. Atesta-o carta enviada pelo líder industrial Euvaldo Lodi ao ministro da Fazenda, na qual afirma que a política tarifária adotada "deixara a melhor impressão nos meios empresariais" (Leopoldi, 2000, p. 116).

Já, a CCAI possui um significado simbólico que não pode ser negligenciado, pois se tratava da primeira vez da criação de um setor dentro do Banco do Brasil voltado à concessão de crédito diretamente à produção, com financiamento em até dez anos para a instalação de novas indústrias ou ampliação das existentes. A Carteira representou um embrião de futuros bancos de desenvolvimento e institucionalizou a concessão de crédito com a introdução de critérios de seleção de caráter técnico, o qual incluía a viabilidade econômica dos projetos.

Na mesma direção, também a legislação trabalhista e duas reformas educacionais - uma no início da década de 1930 ("reforma Francisco Campos") e outra no Estado Novo ("reforma Capanema") - vêm mostrar que o projeto governista abarcava mudanças de vulto no mercado de trabalho urbano.

A legislação do trabalho implicava praticamente a criação de um marco regulatório mediante a definição de regras elementares como de contratação, dispensa, remuneração - até então, inexistentes ou restritas a algumas categorias sindicalizadas. Estas, assim como os "benefícios" - férias, previdência, $13^{\circ}$ salário - só adquirem sentido histórico ao se ter em vista a existência do referido projeto de industrialização, até porque se trata de legislação restrita à economia urbana, pois excluía os trabalhadores do campo - verdadeira marca institucional da formação do mercado de trabalho no Brasil. O Ministério do Trabalho, Indústria e Comércio foi um dos primeiros órgãos a serem criados: em novembro de 1930, um mês após Vargas chegar ao poder. As reformas educacionais, por seu turno, visavam a substituir o ensino exclusivamente "humanista" e preparador de elites, centrado em disciplinas como latim, francês, literatura, história, retórica e filosofia, por outro, mais voltado à preparação de mão de obra para o trabalho e para a produção como as escolas técnicas e os cursos superiores de engenharia, contabilidade, agronomia e veterinária entre outros. Vargas (1938, v. 3, p. 246; grifos nossos) chega a tratar os trabalhadores como o "capital humano aplicável ao aproveitamento integral das nossas condições excepcionais de riqueza", percepção por certo distanciada da visão de mundo das elites agrárias. Na mesma linha, já em 1933, foi proposta a criação, junto ao Ministério da Agricultura, do Instituto de Tecnologia que se vincularia à Diretoria Geral de Pesquisas Científicas. Previa-se, ainda, a criação de duas diretorias, das Minas e das Águas e três centros de pesquisa vinculados à extração mineral: Instituto Geológico e Mineralógico, Laboratório Central de Indústria Mineral e Escola Nacional de 
Química. Assim, foi sendo criada uma série de órgãos, institutos, departamentos e comissões cujo sentido aponta para um comprometimento cada vez maior do estado com a produção, seja industrial ou agrícola ${ }^{3}$.

Diante do exposto, pode-se afirmar, em consonância com as hipóteses formuladas na introdução, que há fortes evidências no sentido de confirmar a existência, já na década de 1930, de um projeto de industrialização deliberado do governo Vargas, com vistas à superação do modelo agroexportador. Mais que se voltar à redistribuição de renda, como frisam as análises sobre o populismo, o referido projeto centrava-se em mudança na estrutura econômica. É o que se pode depreender, com todo o rigor necessário, da análise conjunta da política econômica, dos discursos e das instituições criadas no período.

\section{A indústria no projeto político de Perón}

A polêmica sobre a opção por um projeto industrializante por parte de Perón começa pelas próprias taxas de crescimento do setor. Diferente do Brasil, em que há relativo consenso sobre a importância de 1930 como ponto de inflexão no processo de industrialização, vários autores frisam que na Argentina este já estava em fase realtivamente adiantada quando Perón assumiu a presidência em 1946. Outros, ainda, consideram como "período peronista" a partir 1943, quando iniciou sua participação como ministro no governo militar que derrubou o presidente Castillo, primeiro na Secretaria da Guerra e depois na Secretaria de Trabalho e Previdência.

Como um dos autores mais representativos de um lado do debate, Ferrer (1989, p. 23) entende que de1930 até 1976, o projeto industrialista foi assumido como um objetivo básico na Argentina: assim, este não seria a marca do peronismo, posto que abrangeria também seus adversários. Há, todavia, outra visão segundo a qual a industrialização surgiu por decisão peronista deliberada de impor-se sobre

(3) Além das instituições já mencionadas, pode-se citar, dentre outras, a criação do Departamento Nacional do Trabalho e do Instituto do Açúcar e do Álcool, em 1933; do Conselho Federal do Comércio Exterior, do Plano Geral de Viação Nacional e da Comissão de Similares, em 1934; do Conselho Técnico de Economia e Finanças, em 1937. A partir do Estado Novo e, certamente sob o impulso do contexto de guerra, esta política de criação de órgãos, conselhos e institutos intensificou-se. Datam de 1938 o Conselho Nacional do Petróleo, o Departamento Administrativo do Serviço Público (Dasp), o Instituto Nacional do Mate e o Instituto Brasileiro de Geografia e Estatística - IBGE); de 1939, o Plano de Obras Públicas e Aparelhamento de Defesa e o Conselho de Águas e Energia; de 1940, a Comissão de Defesa Nacional, o Instituto Nacional do Sal, a Fábrica Nacional de Motores e a Comissão Executiva do Plano Siderúrgico Nacional; de 1941, além da Companhia Siderúrgica Nacional, o Instituto Nacional do Pinho, a Comissão de Combustíveis e Lubrificantes e o Conselho Nacional de ferrovias; de 1942, o Serviço Nacional de Aprendizagem Industrial (Senai), o Banco de Crédito da Borracha e a Comissão do Vale do Rio Doce; de 1943, a Consolidação das Leis do Trabalho (CLT), a Companhia Nacional de Álcalis, a Comissão de Financiamento da Produção, a Coordenação de Mobilização Econômica, Fundação Brasil Central, Siderúrgica Social da Indústria (SESI) e Plano Nacional de Obras e Equipamentos; de 1944, o Conselho Nacional de Política Industrial e Comercial, o Serviço Nacional do Trigo, o Instituto Nacional do Pinho e a Comissão de Planejamento Econômico; finalmente, de 1945, a Superintendência da Moeda do Crédito que iria voltar-se a regular uma das mais importantes instituições: a moeda e as políticas monetária e cambial. Para uma lista mais completa, veja Fonseca (2003). 
uma "oligarquia retrógrada" vinculada à produção primária. Quanto às taxas de crescimento, também autores comparam o período peronista com outros, anteriores e posteriores, mostrando-se céticos a referendar a tese de seus compromissos com o setor industrial, como nessa breve comparação de Peña (1986, p.10-12): “de 1935 a 1937 a ocupação industrial cresceu em 108.000 pessoas. Em comparação, de 1946 a 1954 os operários ocupados aumentaram em 117.000 (...) A contribuição da indústria ao produto interno bruto, em dólares de valor constante, foi de $77 \%$ entre 1937 1947 e de 13\% de 1947 a 1957'. Dorfman (1983, p. 64), na mesma direção, explica que, frente ao alto grau de instabilidade da economia argentina, a mensuração do produto industrial pode sofrer grande modificação com a mudança dos anos limites dos períodos considerados. Assim, o PIB industrial apresentou uma taxa de variação anual entre $1935-39$ de 5,1\%, enquanto foi $6 \%$ entre $1940-46$ e $0 \%$ entre $1948-54$. Em contrapartida, se analisamos os anos de 1946 a 1950, esta resulta em 3,6\%, enquanto de 1946 a 1955 foi de 2,3\%. Pode-se perceber que, se não houve variação entre 1948 e 1954, período o qual engloba sete anos da "década peronista", dificilmente se pode falar de "época "industrial", a despeito do crescimento nos primeiros anos de seu governo ou mesmo para quem considera 1943-46 como sendo parte do peronismo. A cifra de 2,3\% para 1946-55 é a menor de 12 períodos selecionados pelo autor entre 1955 e 1980, salvo 1961-63 e 1965-67, que foram negativas.

As taxas de crescimento do período peronista, ao contrário do de Vargas, apresentam grandes oscilações. Assim, no início do governo, as mesmas foram excepcionais: entre 1946 e 1948, respectivamente, 9,6\%, 11,1\% e 5,5\% para o PIB (Cepal, 1958, p. 4).

A partir daí caem, todavia, à medida que a inflação eleva-se e o balanço de pagamentos deteriora-se. Esse desempenho foi muito explorado por autores que modelaram o "populismo econômico" como um ciclo ou trajetória previsível, como Dornbusch e Edwards (1989; 1990), Sachs (1989) e Diaz-Alejandro (1981). Tais modelos partem do pressuposto que os policy makers deparam-se com uma curva de Philips de curto prazo, a qual os força a optar por aumento da produção e do emprego ou por combate à inflação, ou seja, há o velho dilema "crescimento versus estabilização". Afinados com o mainstream, propõem que os governos "populistas" manifestem sua escolha pelo crescimento e redistribuição de renda, subestimando os limites orçamentários e fiscais. Os autores diferem quanto aos instrumentos utilizados, enfatizando um ou outro (salarial, cambial, monetário, gasto público), mas todos convergem ao entendimento segundo o qual a política econômica, em um primeiro momento, centra-se na expansão da demanda agregada, geralmente alavancada pelo consumo. $\mathrm{O}$ "ciclo populista" configura-se porque, como resultado da "vontade política", em um primeiro momento, a economia cresce, gerando até uma euforia, mas em certo tempo começam a aparecer os gargalos. Via de regra, o desfecho é desastroso com uma fase final de recessão, desemprego, inflação e crise 
cambial. Embora não seja objetivo deste trabalho a testagem de "ciclo econômico populista", nota-se que a condução da política econômica no governo de Perón aproxima-se mais dos modelos comparada à de Vargas, inclusive pela ênfase que aquele deu à redistribuição de renda nos primeiros anos de mandato (a "fase inicial" do ciclo, quando o governante revelaria sua "intenção populista"), fato que não se verificou nem no primeiro governo de Vargas, na década de 1930, nem nos anos $50^{4}$.

Do outro lado da controvérsia, há interpretações para as quais o peronismo consistiu em um projeto industrialista. Maceyra (1984, p.15) afirma:

o peronismo vinha a cumprir o papel histórico não assumido pelas burguesias nacionais, fracas e quase inexistentes na semicolônia: produzir a modernização da estrutura produtiva decadente, impulsionando um rápido desenvolvimento industrial e recuperando para o país os recursos fundamentais de sua economia. A miopia dessas burguesias as levaria a serem hostis e somente um setor destas - que cresceria ao amparo desse processo - dar-lhe-ia sustentação mais tarde.

Aintenção de definir o peronismo por seu lado industrializante gera o dilema de explicar a oposição do próprio empresariado industrial. A defesa do projeto peronista como industrializante, em geral,costuma associá-lo a alguma forma de aliança de classes - basicamente trabalhadores, "burguesia nacional" e Forças Armadas iniciada com o golpe de estado de 1943, deflagrado por um grupo de militares, dentre os quais Perón, mesmo não sendo sua liderança formal. Três anos depois, Perón elegeu-se Presidente da República. Com base nisso, Lucchini (1990, p. 80-82) sustenta que tais militares representavam "um projeto de corte industrialista... logo aprofundado pelo General Perón” que "deu resposta às necessidades reivindicadas pelos empresários”, que, por sua vez, "apesar de não compartilharem algumas das medidas sociais adotadas pelas autoridades, compreenderam que, pela primeira, se implementava um modelo que os incluía, ou que, pelo menos, tomava em conta seus interesses". Outro representante reconhecido desse ponto de vista, em geral definido como "esquerda nacional", é Jorge A. Ramos para quem o peronismo executou uma "política econômica que rompia com a tradição da Década Infame"s: "o peronismo

(4) Sobre a inexistência de ciclo político populista nos governos de Vargas, veja-se para a década de 1930, Fonseca (2011b) e para o segundo governo, de 1951-54, Fonseca (2010; 2011a) e Loureiro (2009), este último também com considerações sobre o governo de Perón.

(5) Na Argentina, é conhecida como "Década Infame" a etapa que começa com o golpe de estado de 6 de setembro de 1930 contra o presidente eleito da União Cívica Radical, Hipólito Yrigoyen, até o de 4 de junho de 1943, este último realizado por militares entre os quais se incluía Perón. O termo surge de um livro de 1945, assim intitulado, de José Luis Torres para designar o período em que uma Restauração Conservadora governou, fazendo uso sistemático da violação das regras democráticas (fraude eleitoral, fechamento da União Cívica Radical), repressão política e corrupção generalizada. Ademais, tiveram grande repercussão negativa os acordos econômicos (Pacto Roca-Runciman com o Reino Unido, concessão do transporte público de Buenos Aires à empresa britânica) percebidos como atos de "vende pátria" de uma elite em prejuízo do país. Nesses anos, por sua vez, a atividade industrial desenvolveu-se e houve uma forte migração interna do campo para a cidade, intensificando os problemas sociais. Frente ao descrédito geral do governo e o aguçamento dos conflitos sociais, os militares depuseram o presidente conservador Castillo em 4 de junho de 1943. 
devia expressar os interesses do empresariado nacional, muito frágil para agir por si mesmo" (Ramos, 1991, p. 39; 103).

Para Cafiero (1974, p.143-45), a economia argentina passou de uma "fisionomia monoprodutora, devido à predominante influência das atividades vinculadas à produção agropecuária, subestimando-se as possibilidades do desenvolvimento industrial e mineiro e os serviços ligados à expansão dessas atividades", a outra caracterizada pelo desenvolvimento fabril durante a guerra. Fato "visto com apreensão" por parte das elites e deveria "desaparecer quando se normalizassem as circunstâncias excepcionais", o que o peronismo combateria. Outros autores, como Jorge (1971) compartilham dessa visão do peronismo, mas reconhecem a existência de um período de desenvolvimento industrial nas décadas anteriores a 1943.

As divergências entre as visões expostas requerem uma análise mais detalhada. Em primeiro lugar, o desenvolvimento industrial, que desde o início da Segunda Guerra mundial, ao contrário do Brasil, já era considerável na Argentina, não respalda a interpretação de que houve taxas surpreendentes adstritas ao período peronista, além de as mesmas terem-se concentrado em poucos anos e sob circunstâncias excepcionais. Mais importante, todavia, como metodologia para se detectar um projeto de governo, é evidenciar que a política econômica não parecia estar motivada por um afã industrializante. As decisões de investimento e gasto público, por exemplo, refletem as prioridades políticas que dão sentido à economia peronista: nacionalizações, aumento do orçamento militar e pleno emprego, ainda que a custo da indústria. Não é, portanto, surpreendente que outros autores concluam o contrário, como asseverar que o élan industrialista de Perón não chegou às suas últimas consequências" (Ciria, 1971).

Deixando de lado visões que negam a existência de um desenvolvimento industrial prévio ao peronismo, em sua primeira etapa, este não se diferenciou do processo em marcha já há uma década, enquanto as diretrizes que pretendeu implementar também não diferem das executadas pelos governos posteriores a ele. Geralmente, os defensores da industrialização do peronismo recorrem à evolução da pequena e média indústria entre a guerra e fins dos anos 40. Outros autores, entretanto, chamam atenção que aqueles desconsideram a oposição das grandes empresas: "os proprietários de indústrias dinâmicas, que podiam se considerar beneficiados com as orientações favoráveis ao desenvolvimento manufatureiro, não se transformaram em um ator coletivo com efetiva participação e visibilidade na arena política" (Sidicaro, 2002, p. 62).

A Unión Industrial Argentina (UIA), representante das grandes indústrias, não pareceu respaldar um eventual projeto peronista de intensa industrialização, ao contrário dos setores de médias e pequenas empresas. Conseguiram, todavia, só 
um meio próprio de expressão com a criação da Confederación General Económica (CGE), em meados de 1953, fato que contou com apoio de Perón. Ademais, para Waldmann (1981), a CGE não possuía uma visão econômica muito diferente da perspectiva ortodoxa da UIA, por isso para Ciria (1971, p. 57), não é adequado interpretar o peronismo como tendo recebido apoio da "burguesia industrial nacional".

Indo além da discussão sobre os dados estatísticos, os quais nem sempre permitem evidenciar a intencionalidade nem as variáveis determinantes de suas magnitudes e das possíveis forças sociais que teriam respaldado o peronismo, também envoltas em forte controvérsia, cabe recorrer aos discursos e pronunciamentos do próprio Perón e procurar captar sua percepção e propostas. Esses, de modo geral, não permitem respaldar a tese segundo a qual o peronismo tenha possuído esse "papel histórico" de industrialização. Embora a defesa da indústria apareça em alguns pronunciamentos, tudo sugere que não constitui seu aspecto essencial. Para compreender o projeto político de Perón e sua visão sobre a economia argentina, é central sua idéia de que havia uma expropriação da riqueza do país por parte de grupos nacionais e estrangeiros, responsáveis por deixar a massa da população em situação de pobreza, criando ambiente fértil para a esquerda comunista. Diria Perón (1948a, p. 45): “la Argentina es un país riquísimo que hasta ahora habia sido saqueado por propios y extraños”. Ainda, Perón (1963, p.101) ${ }^{6}$ acrescentaria: "en el orden económico, lo más elemental es recuperar la dirección de nuestra economía, entregada por los partidos políticos a monopolios extranjeros”. O sistema liberal-democrático contribuía para criar esse perigo ao não canalizar demandas insatisfeitas dos trabalhadores e ao incentivar as disputas internas que dividiam o país e alimentavam permanentes conflitos. A solução passaria pelos três princípios com que o próprio Perón definiu o peronismo: justiça social, soberania política e independência econômica. Recuperar essa riqueza era um ato de soberania, por isso caberia ao estado comandar a ordem econômica no lugar dos capitalistas.

Para Perón, a reforma econômica era parte de uma reforma social. O aspecto social da reforma econômica consistia em humanizar o capital, o que não significava terminar com ele, mas torná-lo útil e benéfico para a sociedade, fazê-lo um cooperador efetivo do progresso econômico do país, o que ocorre para Perón (1971, p. 149) "cuando comparte su poderío con el esfuerzo físico e intelectual de los trabajadores para acrecentar la riqueza del país” e não pretende instituirse como "dominador económico". Perón (1973a, p. 175; 178) por isso disse: "El principio de libertad económica que he proclamado no puede, pues, evitar que el Estado realice esta acción tutelar para coordinar las actividades privadas hacia una finalidad colectiva nacional". Para ele não se estava alterando radicalmente a

(6) Optou-se por manter as citações de pronunciamentos de Perón no original para que eventuais nuances dos mesmos não fossem prejudicadas. 
ordem social: ao situar-se do lado do trabalhador, contribuía para preservar o sistema capitalista ou o que este possui de bom em seu entender. O direito de propriedade seria questionável, já que "defender el interés colectivo por encima del interés privado" implicava que a liberdade ao uso do direito de propriedade dependia da avaliação que se fizesse a respeito do cumprimento de "su función social". Perón denominava "economia social” a visão responsável por outorgar ao estado direitos sobre a propriedade privada. Essa, no âmbito interno, condenava o capitalista individual que não fazia uso da riqueza em beneficio da comunidade e, no âmbito externo, os agentes estrangeiros que monopolizavam a riqueza do país e evitavam a distribuição equitativa da mesma. Assim, concluem Gerchunoff e Llach (2007, p. 171): "Fora de certo compromisso geral com a equidade, contudo, não havia no enfoque econômico de Perón um conteúdo essencial e coerente que permita falar de uma 'economia peronista"'. Por sua vez, fica claro que Perón advogava a contemporaneidade de seu projeto, pois concebia o liberalismo, em termos internacionais, como decadente (percepção também presente nos discursos de Vargas). Como expressa Buchrucker (1987, p. 315), para ele tantos os regimes "socialistas" da Alemanha e Itália, como o New Deal e, ainda, o sistema soviético expressavam uma tendência histórica global para formas socializadas, com o desaparecimento de muitas instituições típicas do capitalismo liberal.

É sob tal marco compreende-se que, para Perón, o desenvolvimento industrial era parte da questão social a qual possuía como epicentro a redistribuição de renda. Sua visão sobre a indústria, todavia, era ambivalente tanto com relação ao tipo ou profundidade do desenvolvimento manufatureiro a que o país deveria aspirar, quanto com razões pelas quais se deveria empreendê-lo. Isso se percebe, inclusive, em seu famoso discurso sobre Defesa Nacional, que seguramente constitui o documento mais claro para argumentar a favor da existência de uma visão industrializante (Ferrari, 2007).

No citado documento, assevera que a indústria 'constituye el punto crítico de nuestra defensa nacional'. Prepondera o entendimento de que sua defesa assentase em argumentos militares, por um lado e, por outro lado, em razões sociais. Estas se vinculam ao "Grande Medo", presente no pós-guerra, de retorno da depressão e do elevado desemprego. Se Perón não dá elevado destaque a esse segundo motivo no discurso, pouco depois expressará de forma clara o entendimento de um projeto industrial justificado não em si mesmo, mas como manifestação de uma ação do estado para preservar a ordem social:

La República Argentina produce en estos momentos el doble de lo que consume, es decir, la mitad de lo que produce sale al exterior. Yo me pregunto si cuando termine la guerra será posible seguir colocando nuestros productos en Sudáfrica, Canadá, Centro o Sudamérica, en competición con los EE.UU., Inglaterra, Francia, Rusia, etc. Cuando ya no sea posible exportar, si 
consumimos sólo el 50\%, ¿cuál será la situación de nuestra industria, de nuestra producción? Habrá una paralización del 50\% y veremos a un millón de argentinos desocupados que no tendrán en qué trabajar ni con qué vivir. No habrá otro remedio que aumentar el consumo. Y el consumo, en una circunstancia tan extraordinaria como la que se nos va a presentar, solamente podrá aumentarse elevando los sueldos y salarios para que cada uno pueda consumir mucho más de lo que consume actualmente y permitiendo que cada industrial, cada fabricante cada comerciante, pueda a su vez producir lo mismo que hoy sin verse obligado a parar las máquinas y despedir a los obreros. Los organismos del Estado se hallan abocados al estudio de estas posibilidades (Perón, 1971, p. 143-144).

Assim, conquanto o tema da indústria conste do discurso de Perón, sua abordagem difere da de Vargas, pois aparece mais "como meio" de que "como um fim", além de recorrer a argumentos nem sempre claros sobre que segmentos industriais deveria priorizar-se. Pode-se supor, em tal sentido, que os efeitos sociais de priorizar a indústria de base ou a de bens de consumo, por exemplo, eram muito diferentes, ao menos no curto prazo. A diferença mostrou-se mais evidente quando Perón iniciou sua gestão. Em 30 de junho de 1947 declarava: "Desde hoy en adelante hemos de industrializar al país para que nuestro trabajo lo realicemos con obreros argentinos y ganen lo que antes ganaban los trabajadores de países extranjeros. Esto representa para nosotros la industrialización” (Perón, 1971, p. 178).

O curioso é que sua percepção, ao contrário da literatura defensora de um projeto industrial peronista, subentende que a industrialização já deveria estar em marcha antes de sua chegada ao poder, pois considera a existência de um operariado argentino e a relevância social e política de sua condição ${ }^{7}$. Somente sob essas considerações, pode-se também entender porque Perón, no Congresso Industrial de 1953, defendera o Segundo Plano Quinquenal, afirmando que nele se renunciaria à criação de "una industria pesada para el país, habríamos renunciado a la industria, no a la industria pesada” (Waldmann, 1981, p. 199).

Em outros momentos, parece Perón julgar que a Argentina poderia encarar simultaneamente a expansão de todos os segmentos industriais: a de base, para satisfação militar e a de bens de consumo, para apaziguar os setores populares.

(7) Embora no exílio Perón negasse a industrialização anterior a seu governo, em mais de uma vez pronunciou-se em sentido contrário, inclusive de forma enfática: En 1914 comienza en la Argentina el proceso de industrialización. Entre 1923 y 1930 se acentúa su ritmo; recupera su valor ascensional poco después y, por último, marcha decididamente hacia adelante merced a las necesidades impuestas por la guerra que estalla en 1939. A medida que surgían problemas industriales, y concretamente, conflictos de trabajo o discordias entre patronos $y$ obreros, se siguieron, por comodidad y rutina, las huellas marcadas por otros países que nos habian precedido en las etapas de gestación y desarrollo del maquinismo y consiguiente evolución de los magnos conceptos que informan la estructura, los engranajes y los procedimientos funcionales del complicado mecanismo económico de los Estados Modernos (Perón, 1948, p.28-29). 
Destarte, prepondera no discurso de Perón o entendimento segundo o qual a Argentina não apresentava um problema de riqueza, mas de administração e distribuição, o que contrasta com a visão de Vargas com respeito ao Brasil, cuja percepção era oposta. Para compreender isso, é preciso ter presente a visão de Perón sobre a importância dos trabalhadores como sua base social e política. Durante a campanha eleitoral de 1945, manifestou que a ordem do projeto do governo era "primero la reforma rural, después la industrial y, finalmente, la social. Pero hubo necesidad de alterar el orden de la realización”. Foi preciso, primeiro, efetuar a reforma social, a qual "no podía postergarse ni oponerse a la rural e industrial porque si no nuestros obreros, cuando recibieran los beneficios, ya habrían fallecido de inanición. Por otra parte, yo necesitaba el apoyo de las masas obreras para lanzar estas reformas” (Perón, 1971, p. 120).

Com o fim da guerra e do ciclo de expansão dos setores que haviam dela se beneficiado, verificou-se queda do emprego industrial, calculado em 140.000 pessoas. "Para Perón, esse não era somente um problema econômico, mas também político: seu próprio êxito dependia, em grande medida, do apoio dos trabalhadores" (Gerchunoff; Llach, 2007, p. 165).

Assim, há razões para crer que industrialização não constituía para Perón uma necessidade econômica, mas uma opção política. De fato, em argumento oposto aos defensores da indústria e ao de Vargas, chegou a opor-se a imitar países ricos e apoiar "indústrias artificiais":

En todo momento el Estado puede fomentar o proteger determinadas industrias. Puede pensarse en determinado orden jerarquías dando preferencias a unas sobre otras. Pero, debe evitarse en lo posible la creación o sostenimiento de industrias artificiales, cuya vida económica depende de alguna forma de protección, que directa o indirectamente, siempre representa un gasto. Un mínimo de industria pesada siempre es necesario y conveniente para cubrir las mínimas necesidades de la defensa nacional (...) No debemos imitar a los grandes paises industriales siguiendo el camino que les condujo al poderío de preguerra, porque las circunstancias son otras muy distintas a las que existían en los comienzos de su industrialización. Debemos andar al compás de los tiempos modernos, y crear industrias fundadas en materias primas del país (Perón, 1973a, p.179).

A afirmação segundo a qual o desenvolvimento industrial tem uma visão proeminente nos discursos de Perón de que Perón baseia-se, em grande parte, nas opiniões proferidas durante sua famosa conferência sobre 'Defesa Nacional' na Universidad de La Plata em 1944. Chama a atenção, todavia, que se fosse tal fator tão destacado em seu projeto econômico, por que não se registram referências explícitas a ele em outros pronunciamentos a respeito? Em contrapartida, em pese que ser a exposição de Perón considerada como avançada e moderna com relação à indústria, a mesma permite perceber que, ao contrário de Vargas, mantinha vigente a 
distinção entre artificiais e naturais, ideologia mais adequada aos setores dos setores agraristas. Ademais, não se podem ignorar as circunstâncias do discurso. Para Potash (1985), a célebre exposição teve como objetivo principal impressionar os grupos nacionalistas locais. Assim, Perón retoma a ideia de que a industrialização já percorrera um longo caminho no país e sua preocupação vinculava-se principalmente com as consequências sociais geradas. Sua descrição é coerente com o entendimento de que o problema econômico da Argentina devia-se a uma questão social, ou seja, o monopólio da riqueza por parte das classes abastadas em associação com agentes estrangeiros, em detrimento do povo argentino. Inclusive no mencionado discurso sobre Defesa Nacional, Perón queixava-se do capital estrangeiro por ter-se dedicado especialmente:

a las actividades comerciales, donde todo lucro, por rápido y descomedido que fuese, era siempre permitido y licito" e "en los servicios públicos o industrias madres, muchas veces con una ganancia mínima respaldada por el Estado. La economía del país, reposaba casi exclusivamente en los productos de la tierra pero en el estado más innoble de elaboración, que luego transformaba en el extranjero con evidentes beneficios para sus economías, adquiríamos de nuevo ya transformados (1944).

Como assinala Altamirano (2001, p. 26), nenhum dos temas do discurso de Perón era estranho ao universo ideológico nacionalista. Os setores nacionalistas, cuja maioria apoiara Perón em seu triunfo eleitoral de 1946, logo perceberam que o conteúdo do projeto peronista não seria exatamente o mesmo defendido por eles. Nas palavras de um reconhecido representante de tais tendências, Rodolfo Irazusta (apud Altamirano, 2001, p. 26): "no lugar da revolução que queríamos nacional, aconteceu a revolução social".

Perón compartilhava a visão do setor militar de que a industrialização era importante ao país e os militares deveriam assumir um papel direto na promoção e na administração das empresas industriais. Perón, então, continuava um caminho que já vinha sendo trilhado: "Em 1941 a criação da Direção Geral de Fabricações Militares, sobre a base de um projeto apresentado iniquamente ao Congresso pelo presidente Ortiz, muito antes que Perón aparecesse em cena, afirmou o princípio das empresas industriais dirigidas pelos militares" (Potash, 1985, v. I, p. 407).

Também, para Freels (1970, p. 5), “O movimento de oficiais, que eventualmente levou Perón à presidência, representava uma aliança 'natural' entre um governo militar novo e com mentalidade mais técnica e os interesses industriais cada vez mais afirmados". Essa aliança logo se quebrou com a gestão de Perón na Secretaria de Trabalho e Previdência (STP) a partir de 1943. O triunfo eleitoral de Perón em 1946 não se deveu à defesa da industrialização diante dos políticos que a ela se opunham. Como explica Torre (2002, p. 35), a diferença de Perón com seus 
opositores políticos da Unión Democrática não era por seu programa de governo, que:

não foi menos inovador nem mais conservador que o sustentado pela coalizão peronista. Tanto um como outro se dirigia a um país no qual a industrialização era um processo já irreversível e respondia ao clima ideológico do pós-guerra, com ênfase na intervenção do estado na economia e na distribuição mais igualitária da riqueza.

Também Rouquié (1982, p. 73) ressalta que “a Unión Democrática tinha um programa muito avançado... reforma agrária, nacionalização dos serviços públicos, das fontes de energia e das matérias-primas essenciais. Ampliação da legislação trabalhista e dos direitos democráticos". A diferença principal encontrava-se no lugar de reservado aos setores populares.

Trazer à liça os pronunciamentos de Perón permite o entendimento com mais precisão de autores como Llach (1984), cuja terminologia - 'mercadointernismo' sintetiza a visão econômica de Perón mais como uma defesa do mercado interno e consumo dos trabalhadores do que com a industrialização. A indústria constituía um componente do projeto "mercadointernista" devido ao:

pessimismo de fundo sobre as possibilidades de alcançar os objetivos de progresso social em uma economia aberta. Este pessimismo se fundava em algumas dificuldades encontradas no pós-guerra (como consequência de uma incipiente abertura da economia argentina ao comércio mundial), mas também na desconfiança em relação ao comércio gerada pela Grande Depressão e no entusiasmo com que se via o desenvolvimento industrial durante a Guerra. Por estas razões, o "mercadointernismo" foi visto então como o único caminho apto para manter o alto nível de emprego urbano já alcançado e para aumentar os salários reais. O nível de emprego se converteu em uma verdadeira obsessão ante a iminência do fim da guerra (Llach, 1984, p. 44).

Há várias evidências de que essa defesa do mercado interno devia-se ao caráter social, o qual preponderava sobre os "interesses da indústria". Quando, por exemplo, no início da década de 1950, o governo temeu que pudesse surgir uma crise de abastecimento no mercado interno, com impacto na inflação, "ditou uma série de proibições de exportação, o que demonstrou que dava mais importância à manutenção do equilíbrio econômico interno que ao fomento de empresas particularmente produtivas" (Waldmann, 1981, p. 180).

Inversamente, quando o modelo industrial inicial mostrou suas limitações no início da década de 1950, as decisões do governo para fortalecer os setores patronais não significaram a obtenção do "favor dos grupos opositores, afetados pela firmeza do controle político que o governo exercia sobre o país e pelo espetáculo, exterior, mas nem por isso menos alarmante, da intervenção das massas na vida pública" (Durruty, 1969, p. 14). 
Durante o período em que Perón foi presidente, as forças empresariais sempre se puseram mais contra que a seu favor, a despeito das análises que frisam a ampliação de suas possibilidades lucrativas. Isso ajuda a explicar a existência de várias análises inspiradas em um marxismo mais mecânico que lamentam o fato de a "burguesia nacional" não se interessar ou ser capaz de cumprir suas "missões históricas". A rejeição patronal, no entanto, resulta totalmente compreensível sob a ótica da ordem capitalista, uma vez que sua política econômica e social não raras vezes chocava-se com instituições basilares da sociedade capitalista como o direito de propriedade privada do capital, da terra, dinheiro e outras formas de riqueza individual. Não somente pela questão extrema de expropriação - medida que em Perón fez-se presente mais verbalmente que em atos -, mas também pela ingerência em questões próprias da gestão empresarial no campo e na fábrica, entendida por seus donos como âmbito de seu domínio privado.

Perón, portanto, diferenciou-se dos governos anteriores não por suas visões econômicas ou industrialistas, mas pelo manejo da questão social, ainda que este pudesse causar impactos na economia. Na área política, verifica-se que o foco do conflito entre peronistas e seus adversários não se deveu à questão da prioridade na indústria ou agricultura, mas à política social. É discutível, por isso, afirmar que "parecia, pois, que existiu um contexto estrutural que facilitava a convergência entre os industriais, os militares e a elite política que junto com Perón formou o movimento peronista" (Lucchini, 1990, p. 9).

É preciso recordar que mesmo os grandes empresários industriais da UIA apoiaram a gestão militar iniciada em junho de 1943 e mostraram-se satisfeitos com as medidas adotadas para o setor - inclusive não negavam que existira um desenvolvimento das "indústrias artificiais". Deve-se ponderar, todavia, que tais medidas, embora não fossem contrárias à visão do próprio Perón, dificilmente podem ser atribuídas a resultado direto de sua gestão como ministro. Ações de teor semelhante vinham sendo adotadas, inclusive durante o governo conservador de Castillo, durante a "Década Infame". Não se nega que a indústria pudesse haver sido favorecida durante a gestão de Perón, mas não é por meio dela que se compreende o peronismo. Seu caráter distintivo surge a partir do manejo da "questão social", com o qual alterava práticas tradicionais da cultura política argentina e acenava para outro padrão de redistribuição de renda, riqueza e poder político.

Assim, ao inverso de Vargas, cujo projeto assumia como central a industrialização, procurando costurar um amplo pacto político, inclusive com a participação dos setores agrários, para Perón, as "oligarquias rurais" associadas ao capital estrangeiro "explorador" eram os principais "inimigos da nação" - expressões críticas ou depreciativas ausentes dos discursos de Vargas, a não ser nos meses da crise final de seu governo, mais precisamente na "Carta Testamento" deixada por ocasião de sua morte (Fonseca, 1989, p. 451). 
Vista por outro ângulo, sua percepção era que a indústria não fazia falta tanto pela riqueza que criava, mas pelo que distribuía. O problema da Argentina, portanto, não era a existência de riqueza, mas sua distribuição. Para Perón, a Argentina era um país opulento graças, em última instância, à produção primária. Se a exportação de produtos primários ficasse subordinada a um critério nacional - quer dizer, sem que "capitalistas externos" continuassem a se apropriar de grande fatia - a distribuição equitativa da riqueza do país resolveria as disparidades sociais da Argentina. Esse enaltecimento da "vocação agrária"- ideologia do próprio setor rural, inclusive dos anti-industrialistas - aparece claramente em 26 de abril de 1945: "Estamos frente la Europa destruida. Tenemos campos y tierras fértiles... La República Argentina es casi el único país del mundo que puede criar y engordar a la intemperie...Tenemos la única tierra del mundo que dará cuarenta años trigo sin abonarla” (Perón, 1971, p. 94).

Tudo sugere a partir da leitura de pronunciamentos como este (não isolados) que, para Perón, a atividade econômica fundamental do país era a agropecuária e o setor industrial possuía maior significado por seus efeitos positivos do ponto de vista da geração de empregos e salários, além da defesa nacional. Tal vinculação de Perón entre riqueza e produção primária faz sentido do ponto de vista sociopolítico quando define um "inimigo do povo": a "oligarquia". Como expressa Sidicaro (2002, p. 65):

$\mathrm{O}$ termo oligarquia, já usado anteriormente na linguagem política nacional, a despeito de seu caráter difuso e múltiplo de significados, era empregado pelos peronistas para se referir, em geral, a seus mais ferrenhos adversários, mas a propriedade da terra era o atributo material que mais imediata e fortemente se associava a essa palavra.

Tanto os discursos como a prática peronistas tendiam a considerar como pouco ou nada produtivos, além de não solidários, certos setores sociais, tal como os grandes fazendeiros e os círculos de intermediários ligados à comercialização de produtos de consumo massivo. (Buchrucker, 1987, p. 325).

Essa visão que enaltecia a riqueza do setor primário ao mesmo tempo em que condenava seus proprietários manifestou-se na política externa com a especulação de Perón com respeito à iminência de uma terceira guerra mundial. Miranda, seu primeiro ministro da economia, armazenou duas safras inteiras de milho e linho, retardando a venda em busca de bons preços, ainda que tenha acontecido o contrário. Em suma, antes de concluir o primeiro mandato, Perón alimentava a possibilidade de encaminhar a reforma econômica em meio a um episódio bélico que regenerasse as exportações primárias da Argentina. Não parece existir no peronismo, diante do exposto, a defesa de um projeto econômico voltado a sustentar a necessidade de superar a etapa primário-exportadora do país. Quando se instituiu o Plano Marshall, o governo argentino possuía esperanças de participar por meio da venda de produtos alimentícios. Finalmente, isso não ocorreu, pois a Argentina foi 
excluída. A necessidade de aumentar as exportações primárias aconteceu devido à crise do balanço de pagamentos e ao esgotamento do elevado estoque das reservas internacionais existentes quando Perón iniciou seu mandato em 1946 - resultado da grande quantidade de alimentos que a Argentina havia vendido durante a guerra, sem possibilidade de adquirir importações. Boa parte da literatura atribui como principal causa da escassez de divisas a opção governamental de impulsionar ao máximo a indústria de bens de consumo, cuja característica era demandar mão de obra intensiva. O esgotamento das reservas, no entanto, também coincidiu com a queda nos preços e demanda dos produtos primários nos mercados mundiais. Assim, Perón não teve recursos econômicos para continuar impulsionando a economia e o país entrou em recessão no começo da década de 1950, agravada por uma seca responsável por destruir fortemente a produção primária.

A crise econômica dos últimos anos do governo de Perón alterou em parte seu discurso, pois, diante da recessão, o tema do crescimento começou a receber maior ênfase. Às vezes, passa a impressão de que a crise tomou-o de surpresa, a despeito de só admitir a modificação de suas prioridades quando a situação não permitia alternativa. Assim, em consonância com a hipótese inicial, a seguinte passagem explicita sem deixar dúvidas:

Cuando hubo que mejorar a la clase trabajadora pensé inmediatamente que para logarlo había dos medios: uno, aumentando la riqueza; pero para ello se requería mayor trabajo y no estábamos en condiciones de hacerlo. Tuvimos que recurrir al otro medio, que consiste en quitarle al que tiene para darle al que no tiene (Perón, 1971, p. 122).

Essa explicação novamente deixa claro que, ao iniciar seu governo, a questão do aumento de riqueza não era primordial. Com a crise do modelo econômico é que Perón passou a priorizar a produção no lugar do consumo. A partir daí, cada vez mais manifestaria que "produzir é o dever da hora", já que as possibilidades de distribuição haviam-se esgotado. Waldmann (1981, p. 165) sustenta que houve “indícios de que no ano de 1946, logo após dissolver o Partido Trabalhista, Perón teve intenções de moderar sua postura favorável às classes mais baixas e de retornar a seu projeto inicial, o de impor exigências similares a todos os estratos da sociedade". A declaração de Perón ante os deputados, em outubro de 1946, afirmando que o primeiro ciclo da revolução - o das reformas sociais - houvera concluído e deveria ser seguido pelo aumento da produção e crescimento da riqueza mostra, mais uma vez, que ele admitia ter sido outra sua prioridade até então. Ainda, todavía, para o mesmo autor, "esta intenção de Perón de desligar-se dos estratos mais baixos fracassou", posto que ele "dependia ainda demasiado da classe trabalhadora nesses momentos, para dar-se o luxo de romper a aliança por decisão unilateral sua". $\mathrm{Na}$ verdade, em 23 de julho de 1947 Perón insistiria nessa linha: "la primera etapa de la reforma económica está cumplida y consolidada ... nos queda por delante la segunda etapa, en la que cada uno debe trabajar para producir más” (Perón, 1971, p. 153). 
Se muitas vezes o discurso político mais oculta e dissimula do que esclarece e explicita, seguramente não é o caso de Perón com relação à pesquisa realizada para testar hipóteses em pauta. O próprio Perón demonstra ser muito consciente da transformação significativa que sua gestão propunha e, em parte, conseguiu na ordem social - a qual era sua prioridade e não a industrialização do país em detrimento da agroexportação. Afirma, por exemplo, sobre a revolução de 1943, o seguinte:

fue útil también para despertar la conciencia de las masas merced a la labor de la Secretaría de Trabajo y Previsión... porque ella sirvió, en el aspecto social, para llevar a los trabajadores la confianza en su provenir y la fe en la justicia; $y$ en el aspecto político para hacer ver a esos mismos trabajadores que la reivindicación de sus derechos podia obtenerse sin necesidad de acudir a ideologías extremistas que la inmensa mayoría del pueblo argentino repudia abiertamente. Dessa opção pelos trabalhadores resultou "que la oligarquía desplazada no me ha perdonado nunca” (Perón, 1948a, p. 18-23).

\section{Conclusão}

A análise comparada de Vargas e Perón em temas de natureza econômica mostra algumas semelhanças entre ambos, mas não consegue suprimir importantes diferenças, embora estas sejam bem menos exploradas pela literatura. Quanto aos pontos comuns, não há dúvida de que sejam governos afinados com o desenvolvimentismo, intervencionistas, críticos ao liberalismo econômico e às arenas liberais de representação política - aspectos que não diferem muito de outros governos da mesma época na América Latina e mesmo fora dela. Ambos buscaram respaldo para suas políticas nos sindicatos de trabalhadores e segmentos urbanos emergentes, aos quais se mostraram dispostos a atender reivindicações e fazer "concessões", o que lhes valeu, por parte de seus críticos, a qualificação de "populistas". Da mesma forma, assumiram-se como adversários ferrenhos de seus antecessores (por isso se centra aqui no primeiro período presidencial de Vargas, para entender o sentido e alcance das mudanças com sua ascensão ao poder e permitir sua comparação com Perón), a quem denominavam "oligarcas" e fizeram uso de uma retórica que chamava a si a responsabilidade de liderar uma ruptura e construir nova era. Enfim, ambos se mostraram defensores de um projeto de desenvolvimento econômico com melhor distribuição de renda.

Tais semelhanças, entretanto, são até certo ponto muito genéricas e exigem uma análise com mais acuidade sobre o que cada um pretendia com a intervenção estatal. Também, a que segmentos na prática associaram à imagem de "oligarquia" para uma contraposição e que tipo de ruptura com o passado propunham, qual era a "nova era" a ser construída, mesmo sendo um recurso simbólico de retórica e como imaginavam viabilizar os projetos expressos em seus pronunciamentos. Ao abordarem-se os citados aspectos, começam a aparecer as diferenças. Certamente, elas 
têm a ver com o próprio momento histórico em que ambos assumiram a presidência de seus países: Vargas em 1930, em um país tipicamente agrário e em plena crise internacional que expunha a fraqueza do quase monopólio das exportações do café na balança comercial do Brasil e Perón em 1946, quando a Argentina já estava em um processo relativamente mais adiantado de crescimento industrial, urbanização e sindicalização, bem como em situação mais confortável no balanço de pagamentos com as divisas acumuladas durante a II Guerra.

Diante da conjuntura crítica assumida, Vargas, ao afastar-se de um receituário tipicamente ortodoxo, optou por políticas anticíclicas de curto prazo (desvalorização cambial, crédito, queima de estoques de café e impostos para conter sua oferta) introduzidas em conjunto a mudanças mais profundas voltadas a impulsionar a industrialização do país, ainda muito incipiente e centrada em alguns itens tradicionais de consumo e com tecnologia rudimentar. Era preciso criar instituições, leis e medidas de política econômica cujo epicentro era a transformação da estrutura produtiva do país. Suas críticas feitas aos governos que lhe antecederam ressaltavam o "marasmo agrário", o baixo dinamismo e a "exclusividade cafeeira" e propunham como alternativa a industrialização e diversificação do setor primário e da pauta de exportações. Descendente de família de fazendeiros e vindo de um estado fortemente agrícola, Vargas não via um conflito entre industrialização e setor primário forte - entendia, sobretudo, que ambos deveriam associar-se em um mesmo projeto de modernização e diversificação econômica, sob a liderança do setor industrial. Chegou a criticar as "oligarquias", mas dava ao termo um caráter mais político do que econômico: rotulava assim os adversários que havia derrubado com a "revolução de 1930", quando não havia voto secreto e justiça eleitoral e, no máximo, com ele designava os partidários da "vocação agrária" do país, contrários à industrialização, principalmente defensores da cafeicultura. Vargas jamais criticou a estrutura de propriedade da terra, propôs ou desfraldou qualquer proposta de reforma agrária - entendia que o Brasil possuía terras devolutas, inexploradas e que a colonização poderia contrapor-se à idéia de uma divisão das propriedades existentes. Sob tal aspecto, difere de Perón quanto à trajetória política: este era militar, não fizera carreira política nem descendia de família “oligarca" e ingressou na política já oficial do exército, como membro do GOU (Grupo de Oficiais Unidos), vitorioso no golpe de estado de 1943. Ocupou, a partir daí, vários cargos, mas foi na Secretaria de Trabalho e Previdência que começou a implantar medidas em atendimento às reivindicações trabalhistas, ao mesmo tempo em que afastava seus opositores dos sindicatos. As medidas asseguraram-lhe rápida popularidade. Exonerado do cargo e preso, mostrou sua força com a grande mobilização popular para libertá-lo, o que o credenciou a disputar, em 1946, a presidência da república. Perón, portanto, ascendeu à política à margem dos partidos tradicionais, ao passo que Vargas, desde estudante, fizera carreira política dentro do partido governista em seu estado. Foi deputado 
estadual, deputado federal, presidente do Rio Grande do Sul e ministro da fazenda de Washington Luís - o último presidente do Brasil antes dele e o mesmo que derrubou com a "revolução de 1930". Era, portanto, homem "de dentro" do sistema anterior.

Ao contrário de Vargas, para quem desde estudante concebia o Brasil como uma nação pobre por concentrar-se na exportação de matérias-primas com pouca agregação de valor, precisando, assim, industrializar-se para romper com sua condição periférica, Perón entendia que a Argentina apresentava o contraste de ser uma nação rica com um povo pobre. Essa expressão poderia ser considerada mera frase de efeito não fosse a consequência dela decorrente, com implicações práticas, de apontar o foco do problema argentino não no âmbito da produção, mas da distribuição. Perón não entendia sua tarefa histórica como governante tendo de industrializar a Argentina. Mostrava-se sensível aos interesses industriais, muitas vezes atendeu demandas imediatas do setor, mas, com razão, mais de uma vez referiu-se à indústria de seu país como resultado de um processo de longo curso, cujas origens remontavam ao final do século XIX, quando da chamada Belle Époque argentina ou, em outras vezes, à I Guerra Mundial. Ao assumir, já vigorava na Argentina uma política cambial favorável ao setor industrial, com cotas e licenças prévias para importação, assim como já existiam direitos trabalhistas como jornada de oito horas, descanso dominical, leis de aposentaria e salário mínimo (mesmo que algumas não fossem respeitadas na prática, tal qual no Brasil). Entendia que o divisor de águas que seu governo representava não era imprimir esse novo rumo à economia do país, mas compartilhar com os trabalhadores os "frutos do progresso". Então, Perón, muitas vezes, incluía os próprios industriais entre os "oligarcas", no sentido de que - juntamente aos proprietários de terra, rentistas e banqueiros - eram responsáveis pela pobreza e desigualdades sociais. Assim, no governo de Vargas, as mudanças institucionais e no aparelho de estado, voltadas a alterar a estrutura produtiva foram mais significativas e profundas, pois, ao contrário da Argentina de Perón, a proposta acenava para a alteração do modelo econômico até então vigente.

$\mathrm{Na}$ mesma direção das conclusões, sintetizam Fausto e Devoto (2004, p. 330) que caso por populismo entenda-se não apenas como um "estilo político", mas também um fenômeno com centralidade em seus atores sociais ou institucionais, "constatamos que no getulismo estado-novista esse ator foi o Estado, enquanto em seu segundo período é difícil identificar algum. No peronismo, o ator hegemônico sempre foram os trabalhadores". É interessante notar, todavia, que assim como os discursos ajudam a revelar os projetos e as intenções, quando feitos demarcam e definem seus opositores (a quem, muitas vezes, o discurso é dirigido). Para Perón, abrangiam todos aqueles que ele entendia serem beneficiários com o status quo, portanto responsáveis pela concentração da renda e riqueza. Já, para Vargas, eram segmentos sociais bem mais limitados: os resistentes à industrialização. Então, a utilização de certos adjetivos para ambos, como a designação de "populista", pode 
obscurecer aspectos importantes. Para o caso de Vargas, por exemplo, o termo parece ser menos apropriado, ao considerar-se o que a literatura tradicionalmente considera como populista, como no início mencionado ${ }^{8}$. Do ponto de vista político, ao contrário de Perón, governou em regime inicialmente ditatorial (a repressão e a coerção afastam-se da tipificação categorial da "demagogia populista", que ressalta a coesão, alianças e concessões) e, em 1943, ao vislumbrar o final da guerra e a necessidade de redemocratização, criou dois partidos: um mais conservador, inclusive com forte base rural o Partido Social Democrático (PSD) e outro mais voltado aos sindicatos e setores urbanos emergentes - o Partido Trabalhista Brasileiro (PTB). Uma das características mais marcantes da experiência histórica do Brasil no século XX foi a inclusão de parte significativa dos setores agrários no "pacto desenvolvimentista": em vários países da América Latina isso não foi possível, em prejuízo de um projeto deliberado de substituição de importações (na Colômbia, por exemplo, Alfonso López Pumarejo sofreu forte resistência dos setores agrários associados à Igreja, abortando um projeto que parecia de maior envergadura). Essa engenharia política pretendia abranger amplos setores e supunha admitir a convivência com as formas liberais de representação, ao sugerir a busca de sustentação para assegurar governabilidade, afastando-se da tipologia tradicional que associa populismo à liderança unipessoal e direta com as massas de um líder carismático avesso a arenas intermediárias (a qual parece mais apropriada ao regime peronista, a lembrar Eva Perón). Também, contribuiu para afastar temas como reforma agrária, legislação trabalhista no campo e redistribuição de renda da agenda do governo: a inclusão dos trabalhadores no pacto político respaldou-se, nos governos de Vargas, na introdução da legislação trabalhista urbana e políticas de desenvolvimento econômico. Mesmo que se adote uma definição estritamente econômica para populismo, como fazem Dornbusch e Edwards (1989; 1990), Sachs (1989) e Diaz-Alejandro (1981), a impropriedade do uso do termo não só permanece como até se torna mais visível, já que esses autores, como já se mencionou, partindo-se do pressuposto da curva de Philips convencional de curto prazo, entendem como populismo em matéria econômica a opção inicial do governo por crescimento e redistribuição de renda ignorando a estabilidade. Ambos

(8) Importante aqui é registrar que ambos os governos, de Vargas e de Perón, adotaram medidas de estabilização restritivas voltadas ao equilíbrio orçamentário e do balanço de pagamentos, contrastando com a versão tradicional da ortodoxia segundo a qual os governos desenvolvimentistas e são "populistas" e "irresponsáveis" do ponto de vista das finanças. Todavia, ao contrário de Perón, que começou seu governo com forte crescimento e posteriormente adotou medidas de estabilização restritivas, não se encontra nem no primeiro nem no segundo período governamental de Vargas fases que lembrem ciclo populista. Como já mencionado, a possível exceção seria os últimos meses do segundo governo de Vargas, com o aguçamento da crise política cujo desfecho foi seu suicídio. Em $1^{\circ}$ de maio de 1954, Vargas anunciou um aumento de $100 \%$ no salário mínimo e um conjunto de medidas na área trabalhista acenando claramente para uma opção de maior distribuição de renda. Nesta conjuntura há também uma radicalização sem precedentes de sua linguagem, com forte tom nacionalista, lançando mão de termos como "imperialismo" e "exploradores" para acusar seus adversários e até se declarando adepto do socialismo. Todavia, isso ocorreu ao final de seu governo, e não no início, como preveem os modelos. Ver Fonseca (1989, p. 449-5); Fonseca e Monteiro (2005). 
os governantes, no entanto, não se furtaram a adotar medidas de estabilização e, nos governos de Vargas em particular e de fora mais nítida não se constata um "ciclo econômico populista" da forma prevista pelos modelos.

Havia também em Vargas uma proposta de distribuição de renda, mas esta nunca foi o principal aspecto de sua política econômica nem de seus pronunciamentos, ao contrário, sempre a entendia como algo a ser alcançado juntamente à industrialização do país - subordinava-a, portanto, às exigências de ordem econômica (em outros termos, entendia-a como fruto da realização de seu próprio projeto). Tal posição é típica da ideologia desenvolvimentista, a qual defende o desenvolvimento econômico não só como crescimento do produto, mas o associa a valores éticos e objetivos de maior envergadura (como igualdade, soberania, harmonia social), os quais, para serem alcançados, dependem do próprio crescimento como pré-condição. É notório que mesmo em sua defesa da introdução do salário mínimo, ao lado de entendê-lo como "uma imposição da justiça social", afirmava "tratarse de um mínimo de remuneração, dentro de um critério moderado e equitativo, capaz de evitar aos empregadores exigências incompatíveis com a nossa economia, sob muitos aspectos ainda incipiente e em fase de organização". Também, o padrão de vida da população deveria crescer gradualmente, "aumentando, no decorrer do tempo, [com os] os índices de saúde e produtividade" (Vargas, 1938, v. 5, p. 172; 1944, v. 6, p. 205).

Mais tarde, já na década de 1950, foi mais explícito: “(...) não devemos permitir que uma distribuição insensata venha prejudicar o potencial de capitalização necessário ao desenvolvimento econômico geral, e, assim, a criação de maiores e mais amplas oportunidades de emprego e salário", disse Vargas (1952, v. 1, p. 73). Essas passagens de seus discursos contrastam significativamente com os de Perón antes mencionados e ajudam a mostrar as diferenças de enfoque dos mesmos quanto a temas econômicos.

Note-se, em adição, que nas fases iniciais do processo de substituição de importações, como quando Vargas assumiu em 1930, não havia a rigor problema de mercado para as indústrias nacionais de bens de consumo. O desafio ao governo e ao setor empresarial consistia em criar condições para viabilizar a produção doméstica para atender a demanda pré-existente, até então suprida pelas importações. Esse era o impulso inicial à substituição de importações diante da crise do balanço de pagamentos. Já, Perón assumiu o governo em fase mais adiantada do processo, quando vasta gama de bens havia sido substituída, sendo assim, a demanda "cativa" inicial estava em fase de esgotamento. $\mathrm{Na}$ América Latina, vários economistas com os teóricos da Cepal à frente, em meados da década de 1950, passaram a defender a expansão da demanda que poderia advir de melhor redistribuição de renda em 
análises com forte viés subconsumista. A proposta distributivista de Perón, mesmo que motivada por razões de ordem política, encontraria certo respaldo nessas teses. As diferentes fases de desenvolvimento industrial e a força da economia agrária argentina com produtos mais valorizados (carne, lã, couro, trigo) do que o Brasil (café, açúcar, cacau - desdenhados como "produtos de sobremesa" e de baixas elasticidadepreço e elasticidade-renda) são tão variáveis que não podem ser desconsideradas ao se tentar levantar hipóteses para entender as razões das diferentes ênfases da política econômica de cada um dos governos.

Para finalizar, é conveniente assinalar que uma possível síntese das diferenças entre os projetos de ambos, tendo como material empírico a pesquisa de seus discursos e as principais medidas de política econômica, não pode ser reduzida à questão de temporalidade, ou seja, de quem deveria vir primeiro, o crescimento ou distribuição - ou, ainda, que um dos temas tenha-se mantido ausente dos pronunciamentos e propostas em detrimento do outro. Perón centrava-se na questão distributiva porque entendia que houvera desenvolvimento pregresso, seja pela pujante agroexportação argentina ou por sua indústria, a qual gerara uma riqueza passível de ser distribuída, mas entendia o crescimento econômico e o incentivo às atividades produtivas como necessários. Implementou medidas com esse propósito (principalmente, em seu primeiro governo, como o Plano Quinquenal de 1947, a majoração das tarifas aduaneiras e a continuidade da política cambial anterior, ações com que se pretendia proteger a produção nacional). Já, Vargas centrava-se na necessidade de mudança do modelo econômico: associava a agroexportação não à riqueza, mas à pobreza, à ausência de indústrias e à vulnerabilidade econômica do país. Era, então, o nó a ser desatado para se alcançar melhor patamar de bem-estar, não significando a transferência do problema da distribuição para o futuro, pois sempre argumentou que esta deveria andar em ritmo similar ao crescimento. Também, introduziu medidas com o mesmo propósito (como a própria legislação de "proteção" ao trabalho, que vai além do salário mínimo, como a estabilidade no emprego, direito de férias, previdência social e tribunais especiais frente ao julgamento de causas trabalhistas, importantes marcos regulatórios em um país com oferta elástica de mão de obra e forte êxodo rural).

Enfim, em ambas as experiências históricas de desenvolvimentismo, havia o entendimento de que desenvolvimento e distribuição de renda poderiam e deveriam coexistir, pois eram valores desejáveis e respaldaram-nos em medidas de política econômica. Diferiram quanto às prioridades e aos caminhos para viabilizá-los, por certo em consonância com a trajetória histórica de seus países,necessidades e limites impostos pela conjuntura em que assumiram seus governos. 


\section{Referências bibliográficas}

ABREU, M. P. A ordem do progresso; Cem anos de política econômica brasileira: 18891989. Rio de Janeiro: Campus, 1989.

ALTAMIRANO, C. Encrucijadas políticas y dicotomías ideológicas. Estudio preliminar. Bajo el signo de las masas (1943-1973). Buenos Aires: Ariel-História, 2001. (Biblioteca del pensamiento argentino, v. VI).

AURELIANO, L. M. No limiar da industrialização. São Paulo: Brasiliense, 1981.

BAER, W. The development of Brazilian steel industry. Nashville, Tennessee: Vanderbilt University Press, 1969.

BUCHRUCKER, C. Nacionalismo y peronismo. Buenos Aires: Sudamérica, 1987.

CAFIERO, A. De la economía social-justicialista al régimen liberal-capitalista. Buenos Aires: Eudeba, 1974.

CARDOSO, F. H.; FALETTO. E. Dependência e desenvolvimento na América Latina. 4. ed. Rio de Janeiro; Zahar, 1977.

CEPAL. El desarrollo economico de la Argentina. Santiago de Chile: Cepal, 1958. Disponível em: $<$ http://pt.scribd.com/doc/28814688/El-desarrollo-Economico-de-la-Argentina-CEPALanexos $>$. Acesso em: 21 set. 2011.

CIRIA, A. Perón y el justicialismo. Buenos Aires: Siglo XXI, 1971.

CONCEIÇÃO, O. A. C. Instituições, crescimento e mudança na ótica institucionalista. 2000. Tese (Doutorado)-CPG Economia/UFRGS, Porto Alegre, 2000.

DIAZ-ALEJANDRO, F. C. Southern cone stabilization programs. In: CLINE, W.; WEINTRAUB, S. (Ed.). Economic stabilization in developing countries. Washington, D.C.: The Brooking Institution, 1981.

DORFMAN, A. Cincuenta años de industrialización en la Argentina 1930-1980. Buenos Aires: Solar, 1983.

DORNBUSCH, R.; EDWARDS, S. The macroeconomics of populism in Latin America. Chicago: The University of Chicago Press, 1989. v. 32 , n. 2 , p. $247-277,1990$.

Macroeconomic populism. Journal of Development Economics,

DURRUTY, C. Clase obrera y peronismo. Córdoba: Pasado y Presente, 1969.

FAUSTO, B.; DEVOTO, F. J. Brasil e Argentina; um ensaio de história comparada (18502002). São Paulo: Ed. 34, 2004

FERRARI, A. El peronismo: un fenómeno argentino. Una interpretación de la política económica argentina, 1946-1955. 2007. Tese (Doutorado)-Programa de Pós-Graduação em Economia/UFRGS, Porto Alegre, 2007.

FERRER, A. El devenir de una ilusión. Buenos Aires: Sudamericana, 1989.

FONSECA, P. C. D. Vargas: o capitalismo em construção. São Paulo: Brasiliense, 1989. 
FONSECA, P. C. D. Sobre a intencionalidade da política industrializante no Brasil na década de 1930. Revista de Economia Política, São Paulo, n. 89, p.133-148, 2003.

- Nem ortodoxia nem populismo: o segundo governo Vargas e a economia brasileira. Tempo, Niterói, EdUFF, v. 14, n. 28, p. 19-58, 2010.

O mito do populismo econômico de Vargas. Revista de Economia Política, v. 31, n. 1 (121), p. 56-76, 2011 a.

A revolução de 1930 e a economia brasileira. In: CONGRESSO BRASILEIRO DE HISTÓRIA ECONÔMICA, 9, Curitiba, 2011b. [CD].

; MONTEIRO, S. M. Credibilidade e populismo: a política econômica dos Governos Vargas e Goulart. Revista Brasileira de Economia, Rio de Janeiro, v. 59, n. 2, p. 215-243, 2005.

FREELS, J. W. El sector industrial en la política nacional. Buenos Aires: Eudeba, 1970.

FURTADO, C. [1959]. Formação econômica do Brasil. 15. ed. São Paulo: Nacional, 1977.

GAMBINI, H. Historia del peronismo; el poder total (1943-1951). Buenos Aires: Planeta, 1999. v. 1.

GERCHUNOFF, P.; LLACH, L. El ciclo de la ilusión y el desencanto. Buenos Aires: Emecé, 2007.

JORGE, E. Industria y concentración económica. Buenos Aires: Siglo XXI Editores, 1970.

LEOPOLDI, M. A. P. Política e interesses na industrialização brasileira; as associações industriais, a política econômica e o Estado. São Paulo: Paz e Terra, 2000.

LLACH, J. J. El Plan Pinedo de 1940, su significado histórico y los orígenes de la economía política del peronismo. Desarrollo Económico, Buenos Aires, n. 92, 1984.

LOUREIRO, F. P. Considerações sobre o conceito de populismo econômico: explicação ou distorção histórica? Revista Eletrônica Boletim do Tempo, Rio de Janeiro, ano 4, n. 16, 2009.

LUCCHINI, C. Apoyo empresarial en los orígenes del peronismo. Buenos Aires: CEAL, 1990.

MACEYRA, H. La segunda presidencia de Perón. Buenos Aires: CEAL, 1984.

NELSON, R. R. Recent evolutionary theorizing abaut economic change. Journal of Economic Literature, n. 33, p. 48-90, 1995.

PEÑA, M. Industrialización y clases sociales em la Argentina. Buenos Aires: Hyspanamérica, 1986.

PERÓN, J. D. Seis artículos de Perón. Buenos Aires: Presidencia de la Nación, 1948.

. Tres revoluciones militares. Buenos Aires: Escorpión, 1963.

. Doctrina Peronista. Buenos Aires: Ediciones del Pueblo, 1971.

. El pueblo quiere saber de qué se trata. Buenos Aires: Freeland, 1973.

POTASH, R. El ejército y la política en la Argentina. Buenos Aires: Hyspamérica, 1985.

RAMOS, J. A. La era del peronismo. Buenos Aires: Ediciones del Mar Dulce, 1991. 
ROUQUIÉ, A. Poder militar y sociedad politica en la Argentina; hasta 1943. Buenos Aires: Emecé, 1982. v. I.

SACHS, J. D. Social conflict and populist policies in Latin America. In: BRUNETTE, R.; DELARINGA, C. (Ed.). Labor relations and economic performance. London: MacMillan Press, 1989.

SIDICARO, R. Los tres peronismos. Buenos Aires: Siglo XXI, 2002.

SKIDMORE, T. Brasil: de Getúlio a Castelo. Rio de Janeiro: Saga, 1969.

TAVARES, M. da C. Da substituição de importações ao capitalismo financeiro. Rio de Janeiro: Zahar, 1972.

TORRE, J. C. Introducción a los años peronistas. In: TORRE, J. C. (Dir.). Los anos peronistas (1943-1955). Buenos Aires: Sudamericana, 2002. (Nueva História Argentina, v. 8.)

VARGAS, G. A nova política do Brasil. Rio de Janeiro: José Olympio, 1938-1947. 11v. - O governo trabalhista do Brasil. Rio de Janeiro: José Olympio, 1952.

VILlELA, A.; SUZIGAN, W. Política do governo e crescimento da economia brasileira. Rio de Janeiro: Ipea/Inpes, 1973.

WEBER, M. [1904]. The protestant ethic and the spirit of capitalism. London/New York: Routledge, 1992.

WALDMANN, P. El peronismo 1943-1955. Buenos Aires: Sudamericana, 1981.

WEFFORT, F. O populismo na política brasileira. In: FURTADO, Celso. Brasil: tempos modernos. 2. ed. Rio de Janeiro: Paz e Terra, 1977.

ZYSMAN, J. How institutions create historically rooted trajectories of growth. Industrial and Corporate Change, v. 3, n. 1, p. 243-283, 1994. 